\title{
KEBIJAKAN POLSEK TANDES SURABAYA BAGI KEHARMONISAN RUMAH TANGGA TAHANAN PERSPEKTIF MASLAHAH MURSALAH
}

\author{
Mirza Aziz Didik Putra \\ Mas Darul Huda Jl. Mujahidin No. 123, Sugihwaras, Kec. \\ Sugihwaras Kabupaten Bojonegoro. Email: \\ Putradidik81@,Yahoo.Com
}

\begin{abstract}
This is a field research that aims to find out the policies of the district police of Tandes, Surabaya for the harmony of household prisoners and the analysis of maslabah mursalah on those policies. The result of the research concludes that the policies of the district police of Tandes, Surabaya allow prisoners to meet their families on terms that have been agreed by prisoners and police officers of Tandes, Surabaya. It is an effort to develop cases that are being experienced by prisoners as well as stabilizing emotional condition of the prisoners who have already married. Such policies are in line with maqasid al-shariah and maslabah mursalah concept. All that can be seen from the fulfillment of the five basic guarantees of life (salvation of religion, soul, mind, descendant, and possession) and fulfilled the conditions that exist in maslabah mursalah. It's just that the government's attention to the rights and obligations of prisoners who have already married is felt to be lack. Therefore, the government should pay more attention to the rights of the people in making policy. For the people, they should pay attention to the fate of their families who become prisoners, not to be ostracized because it is not impossible they want to be better than ever.
\end{abstract}

Keywords: Policies of the district police of Tandes, Surabaya, harmony of the bousehold prisoners, and maslahah mursalab

\begin{abstract}
Abstrak: Tulisan ini merupakan hasil dari penelitian lapangan yang bertujuan untuk mengetahui bagaimana kebijakan Polsek Tandes Surabaya bagi keharmonisan rumah tangga tahanan? dan bagaimana analisis maslahah mursalah atas kebijakan Polsek Tandes Surabaya tersebut? Hasil penelitian menyimpulkan bahwa Kebijakan Polsek Tandes Surabaya membolehkan tahanan bertemu dengan keluarganya dengan syarat yang telah disepakati oleh tahanan dan petugas Polsek Tandes Surabaya merupakan upaya pengembangan kasus yang sedang dialami tahanan serta menstabilkan emosional tahanan yang sudah berkeluarga. Adapun bentuk kebijakan Polsek Tandes Surabaya tersebut telah sejalan dengan maqashidus syari'ah dan konsep maslahah mursalah. Semua itu dapat dilihat dari terpenuhinya lima jaminan dasar kehidupan (keselamatan agama, jiwa, akal, keturunan dan harta) serta terpenuhi syarat-syarat yang ada dalam maslahah mursalah. Hanya saja perhatian pemerintah akan hak dan
\end{abstract}

AL-HUKAMA

The Indonesian Journal of Islamic Family Law

Volume 07, Nomor 02, Desember 2017; ISSN:2089-7480 
Mirza Aziz Didik Putra: Kabijakan Polsek Tandes..

kewajiban tahanan yang sudah berkeluarga dirasakan masih kurang, sebab di satu sisi tahanan yang berkeluarga mempunyai kewajiban yang tidak bisa dikesampingkan. Oleh karena itu, pemerintah sepatutnya lebih memperhatikan hak masyarakat dalam membuat sebuah kebijakan dan bagi masyarakat, hendaknya memperhatikan nasib keluarganya yang menjadi tahanan, jangan sampai dikucilkan karena bukan tidak mungkin mereka ingin menjadi lebih baik dari sebelumnya..

Kata Kunci: Kebijakan Polsek Tandes Surabaya, keharmonisan rumah tangga tahanan, maslabah mursalah

\section{Pendahuluan}

Pernikahan merupakan sunnatullah yang umum dan berlaku pada semua makhluk-Nya sebagai jalan berkembang biak dan melestarikan keturunannya serta salah satu pokok hidup yang paling utama dalam pergaulan masyarakat yang sempurna. Dampak dari adanya perkawinan adalah timbulnya hak dan kewajiban masing masing yang telah diatur secara terperinci dalam hukum Islam maupun negara. Salah satu yang paling ditekankan adalah mengenai nafkah seorang suami terhadap istri dan anak-anaknya, baik itu nafkah lahir yang berupa minuman, makanan, pakaian dan sebagainya maupun nafkah batin, yaitu berupa kasih sayang, cinta, serta hasrat seksual. Pemenuhan kebutuhan tersebut membuktikan sebuah tanggung jawab suami sebagai kepala rumah tangga.

Sebagaimana juga firman Allah Swt. dalam surat Al-Baqarah ayat 233 yang artinya: "Dan kewajiban ayah memberi makan dan pakaian kepada para ibu dengan cara ma'ruf'.1 Ayat tersebut merupakan petunjuk yang sangat jelas pergaulan antara suami dan istri, agar keduanya bergaul secara ma'ruf (baik). Dalam artian, memberi nafkah itu wajib bagi suami sejak akad nikahnya sah dan benar. Hakikatnya pergaulan tersebut tidak hanya meliputi aspek materi namun juga aspek immateri atau perasaan berupa hubungan yang baik, perlakuan yang baik, keadilan dan aspek sisi ekonomi yang menjadi penunjang roda kehidupan rumah tangga yang kuat. Dengan demikian, secara tidak langsung menunjukkan peran penting suami dalam memenuhi hajat istrinya, begitu juga istri

1 Departemen Agama RI, Mushaf Al-Qur'an Terjemah (Jakarta: Departemen Agama RI, 2002), 38 . 
mempunyai kewajiban memenuhi hajat seksual suaminya, selama tidak ada halangan atau larangan istri melayani suami.

Sayyid Muhammad Ridhwi dalam bukunya yang dikutip dari hadist Rasulullah saw. menjelaskan bahwa ada kalanya seorang suami wajib melakukan hubungan seksual dengan istrinya sekurangkurangnya sekali dalam empat bulan, sebab ini dipandang sebagai salah satu hak perkawinan bagi si istri. Kewajiban tersebut tetap berlaku selama tidak ada alasan yang sah atau bila si istri membiarkan haknya itu gugur.2 Seksualitas diartikan sebagai suatu pengungkapan emosi, perasaan, watak dan orientas seksual. Terdapat dua konsep makna seksualitas yaitu sex act dan sex behavior. Sex act merupakan konsepsi dari pengertian sex sebagai memiliki anak dan pengungkapan rasa sayang serta cintanya, sedangkan Sex behavior merupakan konsepsi dari pengertian sex sebagai kepuasan belaka.3

Akan tetapi, dalam hal pemenuhan nafkah batin bagi suami istri tidak selalu sesuai dengan penerapannya. Salah satunya karena keberadaan suami istri tersebut berjauhan, mungkin karena terikat kontrak kerja atau karena keadaan tertentu, misalnya berstatus sebagai tahanan di Rutan (Rumah Tahanan), yang sudah tentu harus berpisah sementara waktu karena harus menjalani proses penyelidikan ataupun persidangan. Upaya penahanan yang dilakukan pihak kepolisian sudah tentu memiliki konsekuensi tersendiri, baik bagi suami maupun istri. Dari pihak suami, tidak dapat memenuhi kebutuhan nafkah lahir maupun batin istrinya yang menjadi kewajibannya, begitu pula istri yang tidak bisa merasakan haknya seperti pada umumnya karena terbatasnya ruang geraknya.

Pada dasarnya tidak ada peraturan yang dikeluarkan oleh pimpinan POLRI (Polisi Republik Indonesia) yang mengatur mengenai pemenuhan nafkah batin di dalam tahanan, hanya saja setiap tingkatan lembaga seperti di POLRES (Polisi Resort) mempunyai kebijakan tersendiri, contoh seperti di POLRESTA Medan yang memeberikan pelayanan berupa ruang biologis kepada para tahanannya, sedangkan di Polsek Tandes Surabaya sendiri

2 Muhammad Ridhwi, Perkawinan dan Seks dalam Islam (Jakarta: PT. Lentera Britama, 1996), 92.

3 Rahmat Sudirman, Kontruksi Seksualitas Islam dalam Wacana Islam (Yogyakarta: PT. Media Pressindo, 1999), 31. 
hanya memberikan ruang jenguk, di sisi lain ketika menjenguk tidak boleh ada kontak fisik yang berlebihan antara penjunguk dan tahanan ini dikarenakan takut terjadi kecemburuan sosial antar tahanan. Sebagai pengontrol emosional atau psikologi para tahanan Polsek Tandes Surabaya membolehkan para tahanan untuk menerima sesuatu dari keluarga, umumnya makanan dan pakaian, dari dalam tahanan juga boleh beribadah leluasa.

Hubungan seksual suami istri selain dapat melanjutkan keturunan, juga membawa ketentraman perasaan satu sama lain, terlebih jika suami menjadi seorang tahanan, yang ruang geraknya jelas dibatasi oleh negara dan peraturan dari lembaga itu sendiri, akan menjadikan kebahagian tersendiri bagi suami, juga meminimalisir sebuah pertikaian, perceraian, perzinahan dan penyimpangan seksual yang bisa saja terjadi antara kedua belah pihak. Jika ditinjau dari peraturan perundang-undangan yang dikeluarkan oleh MENKUMHAM (Menteri Hukum Dan Hak Asasi Manusia), yaitu pasal 4 ayat 2 UU No. 2 Tahun 2013 Tentang Tata Tertib Lembaga Pemasyarakatan dan Rumah Tahanan Negara dijelaskan mengenai kewajiban dan larangan narapidana; "Narapidana atau tahanan dilarang melakukan perbuatan asusila dan/atau penyimpangan seksual. Adanya larangan tersebut sebaiknya diimbangi juga dengan sebuah solusi yang bisa meminimalisir kegiatan penyimpangan di dalam rutan".

Dalam hal ini, ajaran agama Islam sendiri juga menganjurkan untuk menjauhi sebuah kemudharoaan yang bisa merugikan diri sendiri atau disini maksudnya para tahanan, maka menurut hematnya diperlukan sebuah maslahah (sesuatu yang baik atau bermanfaat) untuk menjaga tujuan syara' tetap tercapai, yaitu meliputi memelihara agama, memelihara jiwa, memelihara akal, memelihara keturunan dan memelihara harta.4 Jadi maslahab tersebut tidak hanya diukur oleh akal manusia saja namun juga selaras dengan tujuan syarak yang telah dikemukakan di atas. Akan tetapi, tidak semua syara' ada dalilnya. Hal ini disebut dengan maslahab mursalah.

Terdapat perbedaan pendapat dari 4 mazhab yang dipakai oleh Islam mengenai kehujjahan maslahah mursalah ini dan juga

4 Amir Syarifudin, Ushul Figh, jilid II (Jakarta: PT. Kencana, 2009), 245-246. 
mengenai pemenuhan nafkah batin oleh tahanan. Setiap mazhab mempunyai pandangan tersindiri, ada yang membolehkan dengan syarat, ada yang yang menolak seutuhnya. Melihat banyaknya kasus yang sebenarnya dialami oleh tahanan akibat hal yang telah dijelaskan di atas, maka Kebijakan Polsek Tandes Surabaya bagi Keharmonisan Rumah Tangga Tahanan tersebut akan dianalisis lebih dalam menggunakan maslahah mursalah dalam artikel ini.

\section{Konsep Maslahah Mursalah}

Maslahah mursalab merupakan suatu kemaslahatan yang keberadaanya tidak ditopang oleh Alquran maupun hadis yang memperbolehkan atau melarangnya secara tegas penggunaannya.5 Selain pengertian di atas, beberapa ulama' usul figh mempunyai pengertian tersendiri yaitu:

1. Menurut Wahbah as-Zuhaily, maslahah mursalah adalah beberapa keadaan atau tindakan yang sejalan dengan tindakan dan tujuan syara', tetapi tidak ada dalil syara' yang membenarkan atau membatalkan, dan ditetapkannya hukum tersebut manusia akan memperoleh kemaslahatan dan tertolak kerusakan.6

2. Menurut Amin Abdullah, maslahah mursalah adalah menetapkan hukum pada suatu masalah yang tidak disebutkan ketentuanya dalam Alquran maupun sunnah. Penetepan ini dilakukan sebagai upaya mencari kemaslahatan dan menolak kerusakan dalam kehidupan manusia.7

Berdasarkan uraian di atas, maka dapat ditarik kesimpulan tentang hakikat maslahah mursalah itu sendiri, yaitu:

1. Sesuatu yang dianggap baik oleh akal, dengan pertimbangan akan membawa kemaslahatan bagi manusia dan menghindarkan dari kerusakan bagi manusia.

2. Sesuatu yang dianggap baik oleh akal, namun harus selaras dengan tujuan syarak yang sudah ditetapkan dalam menetapkan hukumnya.

5 Noer Iskandar Al-Bansany, et. al., Kaidah Kaidah Hukum Islam (Jakarta: Rajawali, 1989), 126.

6 Wahbah Zuhailiy, Usul al-Fiqh al-Islamiy (t.th: t.tp., t.t.), 757.

7 Amin Abdullah, Mazhab Jogja Menggagas Paradigma Ushul Figh Kontemporer (Jogjakarta: Ar-Ruzz Press, 2002), 234. 
3. Tidak ada petunjuk syara' yang mengaturnya dan yang melarangnya secara khusus.

Berkaitan dengan penggunaan maslahah mursalah sebagai metode penetapan hukum, para ulama berbeda pendapat. Perbedaan ini lantaran tidak adanya dalil yang mengatur keberadaan maslahah mursalab itu sendiri sebagai penggalian dan penetapan hukum. Adapun kelompok yang secara jelas menggunakan metode maslahah mursalah adalah madzhab Maliki. Selain mazhab Maliki, maslabah mursalab juga digunakan oleh kalangan mazhab Hambali. Dua golongan ini menerima dengan catatan harus memenuhi syarat. Penerimaan tersebut berdasarkan beberapa argumen berikut:

1. Tujuan pokok penetapan hukum Islam adalah untuk mewujudkan kemaslahatan bagi umat manusia. Kemaslahatan manusia akan selalu berubah dan bertambah sesuai dengan kemajuan zaman. Dalam kondisi semacam ini, akan timbul masalah baru yang hukumnya belum ditegaskan dalam Alquran dan sunnah. Kalaulah pemecahan masalah baru itu hanya ditempuh melalui metode qiyas, maka akan banyak masalah baru yang tidak dapat diselesaikan oleh hukum Islam, sehingga menimbulkan permasalahan yang serius dan pasti hukum Islam akan ketinggalan zaman. Padahal hukum Islam dituntut untuk mengikuti perkembangan masanya. Untuk mengatasi hal tersebut, dapat ditempuh lewat metode ijtihad yang lain, di antaranya adalah istislah.

2. Di zaman sahabat banyak muncul masalah baru yang belum pernah terjadi di zaman Rasulullah saw. Untuk mengatasi hal semacam itu sahabat banyak melakukan ijtihad yang berdasarkan maslahah mursalah. Sebagai contoh adalah kasus ijtihad sahabat Abu Bakar yang sekaligus khalifah pada masa itu berupa kodifikasi Alquran.

Berbicara mengenai mazhab Syafi'i, di satu sisi menurut beberapa pendapat tidak menggunakan maslabah mursalah ketika berijtihad yang terlihat dari kitab karyanya ar-Risalah yang tidak menyinggung sama sekali, namun di sisi lain, murid dari Imam Syafi'i, yaitu Imam al-Ghazali secara tegas menyatakan kebolehan menggunakan maslahah mursalah sebagai metode menetapkan hukum 
Islam dengan catatan nilai kebaikan yang dikandungnya berkaitan kebutuhan pokok, jelas dan menyeluruh secara akumulatif. 8

Adapun golongan mazhab Hanafi tidak menerima maslabah mursalah sebagai upaya penetapan hukum, namun golongan ini menerima konsep istibsan. Mazhab Syafi'i dan Hanafi menganggap bahwa maslahah musalah dapat menjadi sumber hukum apabila ditemukan nas yang menjadi acuan untuk qiyas. Apabila tidak ditemukan nas dalam suatu maslahab tersebut sebagai acuan qiyas, maka maslahah tersebut dianggap batal, tidak diterima. Selanjutnya golongan Imam Malik dan Imam Hanbali berpendapat bahwa maslahah mursalah dapat menjadi sumber apabila memenuhi beberapa persyaratan.9 Mereka menganggap, bahwa maslahab mursalah merupakan deduksi logis terhadap sekumpulan nas, bukan dari nas yang terperinci, seperti yang berlaku dalam qiyas.10

Alasan-alasan yang disebutkan oleh golongan yang tidak menggunakan maslahah mursalah yaitu:

1. Suatu maslahah akan mengarah kepada bentuk pelampiasan nafsu apabila tidak ditopang oleh dalil khusus.

2. Tidak bisa dibenarkan apabila ada suatu anggapan bahwa pada suatu maslahah terdapat maslabah mu'tabarah, sementara maslahah itu tidak termasuk ke dalam nas atau qiyas, sebab pandangan seperti itu membatasi nash Alquran dan sunnah.

3. Mengambil dalil maslahah tanpa berpegang pada nas akan berakibat penyimpangan dari hukum syariat.

4. Jika maslahah tersebut diberlakukan akan terjadi perbedaan hukum di berbagai negara, tempat dan golongan, karena seharusnya syariat bersifat universal dan sepanjang zaman.11

Untuk menghindari bercampurnya maslahah dengan mafsadah dan hawa nafsu, maka perlu adanya syarat berikut sebagai kualifikasi masalah yang ada:12

8 Amir Syarifuddin, Ushul Figh, 359.

9 Muhammad Abu Zahrah, Ushul Fiqh (Jakarta: Putaka Firdaus, 2007), 428.

10 Nasrun Rusli, Konsep Ijtibad As-Syaukhani (Jakarta: Logos, 1999), 33.

11 Muhammad Abu Zahrah, Ushul Figh, 432.

12 Sulaiman Abdullah, Sumber Hukum Islam (Permasalahannya dan Fleksibelitasnya) (Jakarta: Sinar Grafika, 1995), 153. 
Mirza Aziz Didik Putra: Kabijakan Polsek Tandes..

1. Maslahah tersebut benar-benar maslahah yang hakikat, bukan sebuah perkiraan belaka.

2. Maslahah tersebut bersifat umum, bukan perorangan atau sekelompok orang.

3. Maslabah tersebut sejalan dengan tujuan syariat.

4. Maslahab tersebut tidak bertentangan dengan apa yang ditetapkan Allah.

Dalam ini, al-Ghazali juga berpendapat hampir sama dengan memberi tiga syarat:

1. Maslahah tersebut mesti memiliki sifat mula'imah.13

2. Berada dalam tingkatan daruri atau dalam tingkatan bajiyat yang dapat disamakan dengan tingkatan daruri, sedangkan yang dalam tingkatan tabsiniyat tidak dapat menjadi buijah.

3. Jika berkaitan dengan jiwa, maka maslahah tersebut harus bersifat daruri, qat'i dan qulli. 14

\section{Hak dan Kewajiban Suami Istri menurut Hukum Islam}

Islam telah menetapkan ketentuan yang seimbang antara hak dan kewajiban dalam sebuah keluarga, bukan hanya dalam masalah keluarga, namun juga dalam bermasyarakat. Keluarga yang merupakan unsur terkecil dari sebuah masyarakat menjadikan perantara pembelajaran dalam bersosial yang baik. Hak sendiri adalah apa-apa yang harus diterima oleh seseorang dari orang lain, sedangkan kewajiban adalah apa-apa yang harus dilakukan seseorang untuk orang lain. Kewajiban timbul semata-mata karena hak melekat pada subjek hukum.15 Nabi Muhammad saw adalah figur yang dapat meraih puncak kehidupan manusiawi serta mampu memenuhi tanggung jawabnya dalam upaya menegakkan pilar-pilar agama dan mencetak generasi muslim yang berkualitas. Beban yang dipikul oleh beliau tidak serta merta mengalihkan perhatian beliau sebagai suami idaman yang dicintai istri-istrinya. 16

13Mula'imah adalah tidak terdapat maslahah yang meskipun tidak terdapat nash yang mengakuinya, tetapi ia sesuai dengan tujuan syara'.

14 Abdul Rahman Dahlan, Ushul Figh (Jakarta: Amzah, 2010), 317.

15 Amir Syarifuddin, Hukum Perkawinan Islam di Indonesia (Jakarta: Prenada Media, 2007), 159.

16 Muhammad Ali Al-Hasyimi, Sosok Pria Muslim (Jakarta: Trigendi Karya, 1995), 99. 
Dalam suatu keluarga apabila akad nikah yang dilakukan telah sah, maka sejak saat itu muncullah konsekuensi antara pasangan suami istri tersebut untuk memenuhi hak dan kewajiban masingmasing. Suatu kewajiban akan mengikuti hak, artinya apabila kewajiban tersebut dilaksanakan, maka di situ hak si istri maupun suami akan terpenuhi juga. Oleh karena itu, hak dan kewajiban tidak dipisahkan satu sama lain. Bentuk-bentuk hak dan kewajiban suami istri tersebut antara lain:

1. Hak suami atas istri

Di antara beberapa hak pokok suami terhadap istri dalam hukum Islam adalah menggauli suami secara layak sesuai dengan kodratnya, memberikan rasa tenang dan kasih sayang dalam keluarga, taat dan patuh pada suami selama tidak dalam kemaksiatan, menjaga diri dan harta suaminya bila suaminya sedang tidak di rumah, menjauhkan diri dari mencampuri sesuatu yang dapat menyusahkan suami serta menjauhkan diri dari bermuka masam dan kata-kata yang tidak enak didengar suaminya.17

Dari apa yang dikemukakan di atas hak-hak suami atas istri bukanlah semata materiil namun berupa sebuah moril, sebuah perasaan kasih sayang yang tulus, sebab dalam Islam, istri memang tidak dibebani kewajiban yang berupa kebendaan untuk mencukupi kebutuhan keluarga, bahkan sangat dianjurkan apabila istri tidak keluar rumah dalam artian bekerja, dengan syarat suami telah memenuhi kebutuhan kewajibannya, yaitu memberi nafkah yang cukup bagi keluarga. Hal ini dimaksudkan agar istri dapat mencurahkan perhatian secara utuh untuk membina keluarganya, terlebih jika sudah mempunyai anak, yang sebenarnya cukup berat jika dilaksanakan seutuhnya.

2. Kewajiban suami terhadap istri

Mengingat bahwa seorang suami mempunyai peran sentral dalam sebuah keluarga sebagai pemimpin, maka secara tidak langsung kewajiban seorang suami lebih besar, yang terbagi menjadi dua bagian, yaitu:

17 Abd. Rahman Ghazaly, Fiqh Munakahat (Bogor: Kencana, 2003), 158. 
a. Kewajiban berupa materiil, yang berupa menyerahkan mahar yang telah disepakati oleh kedua belah pihak kepada istri pada waktu yang telah ditentukan oleh istri, baik setelah melakukan hubungan suami istri ataupun sebelumnya18 dan memberikan nafkah kepada istri sebatas kemampuan materiilnya, berupa sandang, pangan dan papan. Nafkah ini hendaklah berupa dari yang halal.19

b. Kewajiban moriil, yang berupa memperlakukan istri dengan cara yang baik, menjaganya dari api neraka dengan cara mengajarkan tentang agama secara komperhensip, serta mencampuri istri dan apabila berada di rumah, suami harus selalu bersikap gembira, mendengarkan pembicaraan istrinya, besikap lemah lembut dan yang pasti penuh kasih sayang.20

Berbicara mengenai nafkah batin, tidak lepas dari peranan suami yang memberikan rasa kasih sayang, mencintai dan perhatian. Semua itu mencakup aspek biologis dan psikologis istri agar tidak tertekan. Berikut beberapa pandang ulama mengenai nafkah batin:

1) Imam Malik mengatakan bahwa wajib suami menggauli istrinya jika tidak dalam keadaan darurat. Jika suami tidak mau menggauli istrinya, maka dipisahkanlah mereka berdua.

2) Imam Syafi'i mengatakan bahwa hukumnya tidak wajib bagi suami menggauli istrinya, karena menggauli istri adalah sebagian hak suami.

3) Imam Abu Hanifah mengatakan bahwa hendaknya diperintahkan suami bermalam di sisi istrinya dan memandanginya.

4) Imam Hanbali menetapkan bahwa mengumpuli istri itu dibatasi, sekurang kurangnya sekali selama empat bulan.21

18 Beni Ahmad Saebani, Fiqh Munakahat I (Bandung: Pustaka Setia, 2010), 11.

19 Wahbi Sulaiman Ghawaji, Sosok Wanita Muslimab (Bandung: Trigendi Karya, 1995), 100.

20 Ibid., 102-108.

21 Hakam Abbas, "Pendapat Ulama tentang Kewajiban Suami", dalam http://hakamabbas.blogspot.co.id/2014/02/pendapat-ulama-tentang-

kewajiban-suami.html, diakses pada 10 Nopember 2016. 


\section{Hak dan Kewajiban Suami Istri menurut Hukum Positif}

Hak dan kewajiban suami istri diatur juga dalam di bab VI pasal 30 sampai dengan pasal 34 Undang-undang No. 1 Tahun 1974 Tentang Perkawinan dan di bab XII pasal 77 sampai pasal $84 \mathrm{KHI}$ (Kompilasi Hukum Islam) dengan rincian sebagai berikut:22

1. Hak dan kewajiban suami dalam Undang-undang No.1 tahun 1974 Tentang Perkawinan

Pasal 30 "Suami istri memikul kewajiban yang luhur untuk menegakkan rumah tangga yang menjadi sendi dasar dari susunan masyarakat."

\section{Pasal 31}

1) Hak dan kedudukan istri adalah seimbang dengan hak dan kedudukan suami dalam kehidupan rumah tangga dan pergaulan hidup masyarakat .

2) Masing-masing pihak berhak untuk melakukan perbuatan hukum.

3) Suami adalah kepala keluarga dan istri adalah ibu rumah tangga.

\section{Pasal 32}

1) Suami istri harus mempunyai tempat kediaman yang tetap.

2) Rumah tempat kediaman yang dimaksud dalam ayat (1) ditentukan oleh suami istri bersama.

Pasal 33 "Suami istri wajib saling mencintai, hormat menghormati, setia dan memberi bantuan lahir batin yang satu kepada yang lain”.

\section{Pasal 34}

1) Suami wajib melindungi istrinya, dan memberikan segala sesuatu keperluan hidup berumah tangga, sesuai dengan kemampuannya.

2) Istri wajib mengatur urusan rumah tangga dengan sebaikbaiknya.

3) Jika suami istri melalaikan kewajibannya masing-masing dapat mengajukan gugatan kepada pengadilan.

22 Departemen Agama, UU No.1 Thn 1974 dan UU No.7 Thn 1989 (Jakarta: Departemen Agama, 1996), 15-16. 
2. Hak dan Kewajiban Suami Istri menurut KHI (Kompilasi Hukum Islam).

a. Kewajiban suami diatur dalam pasal 80 yang terdiri dari 7 ayat yang berbunyi:

1) Suami adalah pembimbing terhadap istri dan rumah tangganya, akan tetapi mengani hal-hal urusan rumah tangga yang penting-penting diputuskan oleh suami istri bersama.

2) Suami wajib melindungi istrinya dan memberikan segala sesuatu keperluan hidup berumah tangga sesuai dengan kemampuannya.

3) Suami wajib memberi pendidikan agama kepada istrinya dan memberi kesempatan belajar pengetahuan yang berguna dan bermanfaat bagi nusa, bangsa dan agama.

4) Sesuai dengan penghasilannya suami menanggung:

a) Nafkah, kiswah dan tempat kediaman bagi istri

b) Biaya rumah tangga, biaya perawatan dan biaya pengobatan bagi istri dan anak

c) Biaya pendidikan anak

5) Kewajiban suami terhadap istrinya seperti tersebut di atas pada ayat (4) huruf a dan dan b berlaku sesudah ada tamkin sempurna dari istrinya.

6) Istri dapa membebaskan suaminya dari kewajiban terhadap dirinya sebagaimana tersebut pada ayat (4) huruf a dan b.

7) Kewajiban suami sebagaimana dimaksud ayat (5) menjadi gugur apabila istri nusyuz.

b. Kewajiban istri dalam rumah tangga diatur dalam pasal 83 KHI, yaitu:

1) Kewajiban utama seorang istri adalah berbakti lahir dan batin kepada suami di dalam batas-batas yang dibenarkan oleh hukum islam.

2) Istri menyelenggarakan dan mengatur keperluan rumah tangga sehari-hari dengan sebaik-baiknya. 
c. Kewajiban dan hak juga diatur bersamaan antara keduanya agar menguatkan satu sama lain yang termuat dalam bab XII pasal $79 \mathrm{KHI}$, yang berbunyi:

1) Suami adalah kepala rumah tangga dan istri ibu rumah tangga.

2) Hak dan kedudukan istri adalah seimbang dengan hak dan kedudukan suami dalam kehidupan rumah tangga dan pergaulan hidup dalam masyarakata.

3) Masing-masing berhak melakukan perbuatan hukum.23

\section{Bentuk Kebijakan Polsek Tandes Surabaya bagi Keharmonisan Rumah Tangga Tahanan}

Pada dasarnya mengenai pemenuhan nafkah batin oleh tahanan tidak lepas dari kebijakan yang diberikan oleh pihak Polsek Tandes Surabaya, bagaimana para petugas memberikan hak-hak tahanan untuk berkomunikasi dengan pihak keluarga dengan memberikan kesempatan untuk membesuk. Tidak semua kegiatan dapat dilakukan oleh suami istri tersebut, sebab sebagai seorang tahanan harus rela kemerdekaanya hilang sesuai dengan asas yang berlaku. Hal ini senada diungkapkan oleh KAPOLSEK Tandes Surabaya:

"Sebagai seorang tahanan harus menerima konsekuensi seperti kehilangan kemerdekaannya dan beberapa ruang geraknya dibatasi, itu sebagai bentuk tanggung jawabnya karena melakukan tindak kejahatan, di samping itu buat efek jera bagi yang lain, kalau di tahanan itu tidak enak" 24

Meskipun demikian tidak serta merta haknya semua ditahan, ada beberapa hak yang memang diberikan oleh pihak Polsek Tandes Surabaya dengan peraturan sebagai berikut:

1. Dalam satu minggu hanya diberikan 2 kali hari besok, yaitu hari selasa dan kamis pada jam $10.00 \mathrm{~s} / \mathrm{d} 14.30$.

Pada kesempatan ini, pembesuk dari pihak keluarga boleh membawa keperluan bagi tahanan, seperti makanan secukupnya dan pakaian seperlunya. Durasi berinteraksi dengan tahanan

23 Departemen Agama, KHI dan UU NO.1 Thn 1974 Tentang Perkawinan (Jakarta: Departeman Agama, 1996).

24 Herman Hosnol Fajar, Wawancara, Polsek Tandes Surabaya, 4 Nopember 2016. 
Mirza Aziz Didik Putra: Kabijakan Polsek Tandes...

tidak dibatasi, namun tidak boleh terlalu lama, sesuai dengan keperluannya saja.

2. Yang boleh membesuk maksimal hanya 3-10 orang saja dengan menunjukkan beberapa persyaratan seperti KTP dan KK.

3. Makan 3 kali sehari selama masa tahanan.

4. Beribadah.

Pemenuhan hak dan kewajiban yang dilakukan dalam tahanan sangat dibatasi oleh peraturan dan kebijakan yang ada di Polsek Tandes Surabaya, sebab petugas tidak mau mengambil resiko berlebihan. Sedemikian ketatnya, ketika ingin menjenguk harus sesuai ketentuan peraturan yang ada. Berikut ketentuan bagi penjenguk yaitu:

1. Pembesuk wajib menunjukkan identitas dan memberikan keterangan tentang keperluannya kepada petugas jaga tahanan.

2. Wajib memberikan kesempatan kepada petugas jaga tahanan untuk memeriksa barang-barang makanan yang dibawa untuk diberikan kepada tahanan.

3. Dilarang memberikan alat komunikasi.

4. Dilarang memberikan barang berbahaya.

5. Tidak memberikan sesuatu/uang kepada petugas jaga tahanan.

6. Terhadap pengunjung/pembesuk yang dengan sengaja melaksanakan perbuatan yang dapat merugikan kepentingan proses penyidikan dapat diproses pidana sesuai ketentuan yang berlaku. 25

Jika bicara tentang tahanan maka tidak lepas dari dua Unit yaitu Unit Reskrim dan Unit SPK (Sentra Pelayanan Kepolisian). Unit Reskrim sebagai penanggung jawab kasus yang dilakukan tahanan dan Unit SPK sebagai penanggung jawab tahanan ketika ditahan. Dalam pengembangan kasus terkadang tahanan ini merasa depresi atau tertekan sehingga kurang koperatif kepada petugas penyidik, oleh sebab itu tahanan meminta kepada petugas agar boleh bertemu dengan keluarga dengan konsekuensi setelahnya harus koperatif. Di saat seperti ini, Unit Reskrim mengajukan "Bon

25 Jastuti Ningsih, Wawancara, Polsek Tandes Surabaya, 03 Januari 2017. 
Tahanan" 26 kepada Unit SPK agar mengizinkan tahanan bertemu dengan keluarganya dengan pertimbangan kepentingan psikologi tahanan. Dalam hal ini, AIPDA Rosullian yang pernah menjadi penyidik mengungkapkan:

"Untuk menstabilkan emosional sebagai kebutuhan batin tahanan atau keluarganya, dari pihak Polsek yang pertama memberi kegiatan Rohani dalam satu minggu sekali, biasanya ada juga yang rindu dengan istri dan anaknya sehingga waktu penyidikan meminta bertemu dengan mereka, hanya sekedar memeluk istri dan anaknya. sebagai penyidik (atas izin pimpinan) mengizinkan hal semacam itu, caranya memberi durasi waktu dan ditempatkan di ruang khusus dengan penjagaan dari pihak penyidik. Jika mempunyai anak biasanya waktu untuk anak lebih lama." ${ }_{27}$

Dari hasil yang telah diupayakan, diharapkan dapat memperlancar penyidikan atau dalam pengembangan kasus yang dihadapi, sehingga menguntungkan antara polisi dan tahanan, namun adakalanya Unit Penyidik atau Unit SPK tidak mengizinkannya, karena suatu alasan berikut:

"Memang ada kalanya tidak dizinkan, karena dari kami melihat dulu kasus apa yang dilakukan oleh sitahanan, kalau dirasa potensi membayakannya lebih besar maka kami tidak mengizinkan dan tidak semua penyidik bisa dimintai izin seperti itu (izin ketemu keluarga)." 28

Beberapa tahanan memang dikualifikasikan ketika mengajukan izin bertemu keluarga, sebagai contohnya tahanan yang dikenakan pasal 365, yaitu pencurian dengan kekerasan. Jika tahahan yang dikenakan pasal ini diberi izin takutnya keluarga dibuat sebagai sandera atau hanya sebagai kedok belaka agar bisa kabur. Hal seperti itulah yang ditakutkan polisi jika leluasa memberi izin bertemu keluarga. Akan tetapi apabila tahanan tersebut meminta

26Semacam surat peralihan tanggung jawab jika terjadi sesuatu pada tahanan, semisal kabur atau ada kejadian yang tidak diinginkan menjadi tanggung jawab tangan kedua (Unit RESKRIM).

${ }_{27}$ Rosullian, Wawancara, Polsek Tandes Surabaya, 12 Nopember 2016.

${ }_{28}$ Hendri Prasetyo, Wawancara, Ruang Penyidik Polsek Tandes Surabaya, 03 Januari 2017. 
bertemu (bercengkrama) dengan keluarga pada hari besuk yang telah ditentukan,malah tidak boleh. Takutnya terjadi iri hati antar tahanan yang pada akhirnya membuat tidak kondusif.

Berikut hasil wawancara dengan 5 orang tahanan:

1. Pendik Wijayanti bin Herman

Dengan keterbatasan ruang gerak akibat tindak kejahatan yang saya lakukan, saya sangat kesulitan mas apalagi dalam masa penahanan seperti ini. Kalau sudah tertangkap seperti ini saya merasa menyesal. Jadi jalan satu-satunya mengizinkan istri mengelola harta yang ada dirumah, entah itu dibuat buka usaha atau keperluan sehari-hari, terserah mereka yang mengaturnya.

2. Freno Febriyanto

Selama saya sebagai tahanan yang masih dalam proses penyidikan, Tidak banyak yang bisa saya lakukan mas, palingpaling ya kalau istri minta pendapat waktu jam besuk, sebagai suaminya saya kasih tahu yang terbaik dan sebagai kebutuhan sehari hari istri saya bekerja sendiri mas. Ada rasa menyesal kalau sudah menjadi tahanan. Tapi saya harus bertanggung jawab atas apa yang saya perbuat.

3. M. Dulgani bin Dahruji

Untuk masalah hak dan kewajiban saya banyak lalainya mas, waktu sebelum menjadi tahanan saya menafkahi istri ala kadarnya saja. Di sisi lain kerja saya yang tidak tetap atau serabutan, apalagi ketika menjadi tahanan seperti ini. Hanya sebagian keluarga yang datang membesuk. Ini dapat kabar kalau istri saya meminta cerai, karena merasa malu akibat perbuatan saya. Untuk biaya kebutuhan sehari hari saya serahkan apa yang ada di rumah untuk dikelola.

4. Yahya bin Munaji

Dalam hal pemberian nafkah saya mengizinkan istri saya untuk bekerja di pabrik atau mengelola harta yang ada di rumah, entah itu mau di \jual atau buka usaha terserah istri saya mas. Waktu dijenguk mengucapkan kata kata yang baik, ramah dan mesra. Saling bertukar pendapat. Dan kepinginnya untuk kedepannya saya lebih baik lagi, kasihan keluarga besar yang menanggung malu mas. Anak istri saya yang ada di rumah tidak tenang. 
5. Harold Imanuel Anakotta bin Niko Anakotta

Saya merasa kecewa dengan diri saya, istri saya menangung malu di rumah, kangen juga kumpul dengan keluarga, tapi saya harus bertanggung jawab dengan apa yang saya lakukan, mengenai nafkah saya memberikan apa adanya, berusaha ramah ketika dijenguk oleh istri, memberi saran yang baik ketika dia meminta pendapat, cukup saya saja yang seperti ini mas. Untuk kedepannya semoga lebih baik lagi.

Selain kepada para tahanan laki-laki, wawancara juga dilakukan kepada pihak istri tahanan, karena memang konteks dari kebijakan ini agar keharmonisan rumah tangga tahanan tetap terjaga. Berikut hasil wawancara yang telah dihimpun:

1. Shinta Abimanyu

Saya ini cuma ibu rumah tangga biasa mas, lihat suami saya masuk penjara seperti ini saya sempat pusing dan putus asa. Suami saya hanya meninggalkan saya beberapa harta di rumah mas kayak gelang, cincin ya itu saja yang bisa saya jual buat jualan donat, kue lapis dan jajan pasar lain. Saya sering rindu terhadap suami saya, saya selalu berdoa agar suami saya segera keluar dari penjara.

2. Diah Mayasari

Saya sebenarnya jengkel dengan suami saya kelakuannya tidak pernah benar, saya pernah mikir untuk minta cerai saja dengannya tapi kalau dipikir-pikir lagi kasihan anak-anak. Aaya diuntungkan dengan pekerjaan saya, meskipun hanya penjaga gudang toko di PGS lumayan buat nutup kebutuhan sehari-hari. Ada suami ataupun suami tidak ada sangat tidak berpengaruh buat saya mas.

3. Siti Ambarwati

Saya bukan istrinya mas, istrinya sudah tidak mau menemui dik Dul lagi, di rumah sudah ada surat gugat cerai untuk dik Dul. Kalau ditanya istrinya dinafkahin atau tidak setahu saya adik saya kerjaannya tidak pasti, kalau ada borongan ya ikut kerja. Itu juga mungkin yang membuat istrinya minta cerai.

4. Imamah Fauziyah

Saya sudah ikhlas mas suami saya masuk penjara biar dihukum di dunia saja. Saya nerima suami saya apa adanya mas, 
tidak ada dipikiran saya untuk minta cerai, kasihan anak-anak mas. Soal nafkah saya sudah diizinkan suami saya untuk bekerja mas, jadi tidak ada kekhawatiran buat saya dan keluarga. Doa saya selalu untuk suami saya agar suami saya segera bebas dari penjara.

5. Feronika Agatha

Ya sejujurnya saya sedih mas melihat suami ditahan karena kelakuannya tapi bagaimana lagi sudah terlanjur terjadi, saya selalu mendukung dia ketika di tahanan dan melalui semua prosesnya. Setiap saya jenguk suami saya dipenjara kelihatan senang, rindu juga sama saya. Saya juga kebetulan sudah lama bekerja jadi tidak ada masalah soal kebutuhan sehari-hari. Tidak pernah terlintas dalam benak saya soal perceraian.

Ada beberapa yang dikeluhkan oleh petugas yang sudah lama ditempatkan di Polsek Tandes Surabaya, salah satunya keluhan mengenai kurangnya anggota yang ada.29 Hampir semua unit kekurangan anggota, mulai dari Unit SPK, Unit Reskrim, Unit Intel dan beberapa jajaran Unit lain. Jika diakumulasikan total semua anggota yang ada tidak mencapai 100 orang, padahal sebaiknya tingkat Polsek Kota seharusnya ada 100 anggota lebih, agar lebih kondusif dalam menjaga stabilitas keamanan dan pelayanan baik di dalam maupun di luar MAKO (Markas Komando). Hal semacam ini sangat dirasakan oleh Unit SPK, sebagai garda terdepan dalam melayani masyarakat terkadang merasa kewalahan, apalagi ketika tahanan banyak dan waktu hari besuk. Dampaknya adalah para tahanan yang seharusnya bisa dengan leluasa berinteraksi dengan pengunjung atau bahkan ingin memenuhi kewajibannya sebagai seorang suami jadi tidak maksimal karena tidak adanya personil yang memadai untuk menjaganya. Sebagai ganti penjaga khusus yang tidak ada, pihak Polsek Tandes Surabaya memasang CCTV di ruang besuk.

\section{Analisis Mas\{lahah Mursalah atas kebijakan Polsek Tandes Surabaya bagi Keharmonisan Rumah Tangga Tahanan}

Maslahah mursalah timbul karena tidak adanya dalil dari Alquran yang menjelaskan benar tidaknya tindakan yang dilakukan

${ }_{29}$ Beni Suhartono, Wawancara, Ruang SPK Polsek Tandes Surabaya, 27 Desember 2017. 
manusia, sehingga dengan tujuan yang baik dan demi kemashlahatan bersama digunakan sebagai penetapan hukum Islam. Meskipun terjadi khilaf antar ulama tentang penggunaan maslahah mursalah, namun sejatinya syariat Islam diturunkanya demi kemaslahatan umatnya. Jika terjadi perubahan hukum maka itu sepenuhnya kembali kepada kemaslahatan bersama dan hukum berkewajiban untuk mengikuti perkembangan zaman sesuai dengan kemaslahatan, sesuai dengan kaidah figh fikih yang berbunyi: "Tidak dipungkiri bahwa perubahan hukum terjadi dengan berubahnya waktu dan keadaan".30

Pembaharuan hukum Islam manjadi sangat penting di zaman ini, supaya hukum Islam dapat menjawab segala permasalahan yang baru muncul saat ini. Hal ini selaras dengan apa yang dikatakan oleh Abdul Mannan bahwa pembahruan hukum Islam perlu dilakukan karena beberapa faktor:

1. Memberikan aturan hukum karena terdapat beberapa persoalan yang belum diatur oleh kitab fikih.

2. Pengaruh globalisasi dan kecanggihan tekhnologi yang belum ada aturan hukumnya.

3. Pengaruh reformasi dalam berbagai bidang yang memberikan peluang bagi hukum Islam sebagai acuan dalam penetapan hukum nasional.

4. Pengaruh pembaruan hukum Islam yang dilakukan oleh mujtahid tingkat nasional maupun internasional.31

Dalam kaitannya dengan kebijakan Polsek Tandes Surabaya bagi tahanan dalam pemenuhan nafkah batin perlu payung hukum yang jelas. Selama ini, perhatian terhadap kebijakan dalam pemenuhan nafkah batin kurang begitu terlihat dan juga tidak adanya sarana yang memadai di beberapa lembaga terkait, baik di Lapas maupun Rutan. Berdasarkan penelitian terdahulu, terungkap beberapa fakta diantaranya adalah banyaknya terjadi kasus perceraian dan kelainan seksual yang dialami tahanan setelah keluar dari penjara. Hal ini menjadikan tujuan dari penjara sedikit

30 Abdul Karim Zaidan, Al-Wajiz 100 Kaidah Fiqib dalam Kebidupan Sehari-hari, terj. Muhyiddin Masrida (Jakarta: Al-Kautsar, 2008), 169.

31 Abdul Mannan, Reformasi Hukum Islam di Indonesia (Jakarta: Rajawali Press, 2006), 153. 
menyimpang, bukan menjadikan lebik baik seseorang tetapi bisa membawa mafsadat bagi tahanan.

Jika dikaitkan dengan konsep maslahah yang bertujuan untuk kepentingan umum, maka tidak lepas dari maqasidus shari'ah, yang meliputi lima jaminan dasar yaitu: keselamatan agama, keselamatan jiwa, keselamatan akal, keselamatan keturunan dan keselamatan harta. Untuk melihat relevansi kebijakan yang diambil oleh Polsek Tandes Surabaya kaitannya dengan keharmonisan rumah tangga tahanan dengan konsep maslahah maka terlebih dahulu harus dilakukan pengkajian satu persatu.

Pertama, para tahanan bisa bertemu dengan keluarga pada waktu jam besuk. Pada waktu bertemu dengan keluarga, tahanan berusaha semaksimal mungkin untuk mengungkapkan hal-hal yang baik dengan tujuan menenangkan si istri agar tabah dan memaafkan perbuatan si tahanan. Apa yang dilakukan senada dengan tujuan syariat, yaitu menyelamatkan keluarganya dari perceraian. Bukan tidak mungkin jika si istri tidak kuat menahan tanggung jawab sosial karena malu mempunyai suami yang menjadi tahanan akhirnya memintai cerai, sebagaimana hasil wawancara salah satu tahanan berikut:

"Di sisi lain kerja saya yang tidak tetap atau serabutan, apalagi ketika menjadi tahanan seperti ini. Hanya sebagian keluarga yang datang membesuk. Ini dapat kabar kalau istri saya meminta cerai, karena merasa malu akibat perbuatan saya. Untuk biaya kebutuhan sehari hari saya serahkan apa yang ada di rumah untuk dikelola." 32

Bukan hanya pada keselamatan keturunanya saja namun keselamatan agama, sebab sebuah perceraian sangat dibenci oleh Allah SWT dan perkawinan merupakan bentuk penyempurnaan agamanya sebagaimana sabda Nabi muhammad saw. berikut:

"Siapa yang diberi karunia oleh Allah seorang istri yang sholihah, berarti Allah telah menolongnya untuk menyempurnkanan setengah agamanya. Karena itu, bertawalah kepada Allah setengah sisanya".

32 M. Dulgani bin Dahruji, Wawancara, Surabaya, 23 Desember 2016. 
Kedua, tahanan bisa mengajukan izin bertemu keluarga di luar jam besuk yang merupakan inisiatif tahanan untuk bertemu keluarga jika rindu dengan mereka, baik dengan istri ataupun anaknya. Para tahanan ingin menjadi lebih bermanfaat lagi bagi keluarganya bukan hanya menjadi sumber masalah. Hal ini dilakukan agar keselamatan jiwanya terjamin dan juga akalnya, maksud dari keselamatan jiwa merupakan keselamatan bagi kehormatannya, dengan begitu tahanan tidak merasa diabaikan dan merasa berguna. Oleh karena itu, aturan-aturan yang disyariatkan untuk menjamin eksistensi jiwa, sekaligus dimaksudkan untuk menjamin eksistensi akal. Allah berfirman dalam surat At-Tahrim ayat 6 yang berbunyi:

"Hai orang-orang yang beriman, peliharalah dirimu dan keluargamu dari api neraka yang bahan bakarnya adalah manusia dan batu; penjaganya malaikat-malaikat yang kasar, keras, dan tidak mendurhakai Allah terhadap apa yang diperintahkan-Nya kepada mereka dan selalu mengerjakan apa yang diperintahkan." ${ }_{33}$

Ketiga, tahanan membolehkan istrinya bekerja untuk biaya kehidupan sehari-hari dan membolehkan mengelola barang yang ditinggalkan oleh tahanan agar harta benda tersebut bernilai manfaat. Para tahanan menyadari bahwa tidak bisa lagi menafkahi secara layak sehingga hal itu menjadi jalan satu-satunya agar istri yang ditinggalkan dapat bertahan hidup.

Dari analisis di atas, lima unsur yang terkandung dalam maqasidus shariah sudah tercakup di dalamnya. Jumhur ulama sepakat bahwa tujuan hukum harus mengandung lima unsur tersebut. Adanya lima unsur tersebut sejatinya untuk meraih manfaat dan menolak kemudharatan yang ditakutkan semata-mata demi kepentingan keduniawian saja tanpa dilandasi agama. Maqasidus shari'ah merupakan syarat mutlak tindakan tersebut sejalan dengan nilai-nilai yang terkandung dalan ajaran Islam atau tidak. Apabila sudah tercakup, maka sebagai penguat alasan yang dilakukan oleh tahanan sejalan dengan maslabah mursalab harus memenuhi beberapa syarat yang telah dipaparkan sebelumnya, yaitu:

33 Departemen Agama RI, Al-Qur'an dan Terjemahnya, 286. 
1. Maslahab tersebut benar-benar maslabah yang hakikat. Apa yang terjadi bukan sebuah perkiraan belaka. Memberi nafkah kepada istri merupakan tanggung jawab suami, yang sudah terikat sejak akad nikahnya sah. Bagaimanapun keadaan suami wajib memberikan sesuai dengan kemampuannya seperti yang sudah dinashkan oleh Allah Swt. dan kewajiban tersebut tidak bisa diwakilkan kepada lain pihak. Dengan demikian, kebijakan yang dikeluarkan Polsek Tandes Surabaya sudah mencakup syarat pertama.

2. Maslahah tersebut bersifat umum, bukan perorangan atau sekelompok orang. Manfaat kebijakan tersebut dirasakan manfaatnya oleh lebih dari sekelompok orang, yaitu oleh banyak tahanan beserta keluarganya. Ini sesuai dengan prinsip maslabah yang disampaikan Imam asy-Syathibi, bahwa maslahab harus bermuara pada kepentingan manusia yang mana membawa manfaat dan menghindarkan dari mafsadat.34

3. Maslahab tersebut sejalan dengan tujuan syariat. Apabila dikaitkan dengan syariat, kebijakan tersebut telah senafas dengan tujuan syariat Islam yang meliputi lima pokok kehidupan berupa menjaga agama, menjaga jiwa, menjaga akal menjaga keturunan dan menjaga harta. Meskipun kebijakan tersebut tidak dapat dijumpai dalam Undang-Undang No. 6 tahun 2013 Tentang Tata Tertib Lapas dan Rutan, tetapi kebijakan tersebut telah mengandung kemashlahatan, sebagaiamana disebutkan dalam kaidah fikih: "Kebijakan seorang pemimpin atas rakyat harus berdasarkan kemashlahatan." 35

4. Maslahab tersebut tidak bertentangan dengan apa yang ditetapkan Allah Swt. karena dalam Alquran maupun hadis, tidak ditemukan larangan terhadao kebijakan yang menyangkut bertemunya tahanan dengan keluarga secara utuh, hanya ada pendapat ulamaulama dari empat madzhab yang bisa dijadikan sebagai acuan.

Pendapat pertama, yaitu suami dilarang untuk berhubungan badan dengan istrinya saat ia menjadi tahanan. Alasannya karena tujuan pokok penahanan adalah membuatnya merasa jera dan

34 Abdul Rahman Dahlan, Ushul Fiqh, 304.

35 Abdul Haq, Formulasi Nalar Figh Telaah Fiqh Konseptual (Surabaya: Khalista, 2009), 75. 
tersiksa sehingga tahanan tidak mengulangi kesalahan dan kejahatannya lagi, sehingga ketika tahanan diperbolehkan melakukan hal itu dengan istrinya, maka tidak ada unsur menyiksa hatinya, membuatnya resah dan efek jeranya kurang dan juga bersenggama bukanlah kebutuhan pokok sebagaimana halnya makan. Ini pendapat ulama madzhab Maliki, sebagian madzhab Hanafi dan sebagian madzhab Syafi'i.

Kedua, seorang suami tidak boleh dilarang untuk memenuhi kewajibannya kecuali jika ada maslahat dalam pelarangannya. Termasuk kewajiban pemenuhan nafkah batin tersebut, sebagaimana pelarangan sholat jum'at, dan hal ini sepenuhnya tergantung kebijakan kepolisian. Pendapat ini dikeluarkan ulama madzhab Syafi'i.

Ketiga, pandapat terakhir dirinci menjadi tiga bagian, yaitu:

1. Suami boleh bersenggama dengan istrinya d imasa penahanannya apabila memang di penjara tersebut ada tempat khusus yang tidak akan terlihat orang lain, sebagian ulama menambahkan bahwa syarat tempat haruslah layak.

2. Auami tidak diperbolehkan berhubungan badan dengan suaminya apabila tidak ada tempat khusus. Pendapat ini diutarakan oleh ulama madzhab Hanbali, mayoritas ulama madzhab Hanafi dan sebagian ulama madzhab Syafi'i dengan argumentasi bahwa jika suami tidak dilarang untuk memenuhi syahwat perutnya dengan makan dan minum, maka ia juga tidak diarang memenuhi syahwat lainnya, karena tidak ada ada perkara yang menjadikan gugurnya kewajiban tersebut.36

Berdasarkan konsep maslahah mursalah, dapat ditarik kesimpulan bahwa kebijakan tersebut telah sesuai dengan prinsip agama Islam (maqashidus syariah), selanjutnya kebijakan tersebut dikaitkan pada keharmonisan rumah tangga tahanan, keharmonisan akan terwujud jika didalamnya ada sikap saling menghargai dan menyayangi, suami maupun istri harus dapat membuat pasangannya merasa dibutuhkan secara moril, bukan hanya materiil, karena pada dasarnya tugas rumah tangga dibagi rata, dipikul bersama dan saling bertanggung jawab. Karakteristik di atas dapat dikorelasikan, yaitu

36 Ubaid bin Aziz Hasanan, "Hukum Berhubang Intim di dalam Penjara", dalam www.fikihkontemporer.com, diakses pada 25 Januari 2017. 
melalui data hasil wawancara dari tahanan dan juga para istri tahanan, yang mana terdapat variasi jawaban yang berbeda-beda, untuk para istri dari lima narasumber yang telah dipilih memberikan jawaban sangat mendukung akan kebijakan ini karena memang sangat terbantu bagi keharmonisan keluarganya, meskipun waktu yang diberikan sangat sedikit untuk bertemu. Indikasi terciptanya keharmonisan tersebut dapat dijumpai dari ungkapan istri tahanan Harold Imanuel Anakotta, yaitu Feronika Agatta yang selalu mendukung suaminya dalam keadaan terpuruk dan menjalani proses dalam tahanan.

Dalam ajaran agama Islam sendiri menjaga keharmonisan rumah tangga merupakan sunnabtullah yang telah diajarkan oleh Nabi Muhammad saw. yang sangat mencintai istri istrinya, begitu juga sebaliknya, istri-istri beliau menyayangi Nabi Muhammad dalam keadaan apapun, sehingga tujuan dari perkawanian dapat terpenuh sebagaimana sabdanya:

Mukmin yang paling sempurna imannya adalah yang paling baik akblaknya, dan sebaik-baiknya kalian adalah yang paling baik terbadap istriistrinya. (HR. At-Tirmidri No. 1162)

Selain itu, ada beberapa yang berakhir perceraian. Hal seperti itu, tidak bisa dihindari dan bisa saja terjadi pada tahanan lainnya, seperti narasumber yang bernama Siti Ambarwati. Dari data yang dihimpun, memang sebelumnya sudah terjadi percekcokan antara suami istri tersebut karena faktor ekonomi ditambah lagi karena faktor keduanya yang tidak mau mengerti satu sama lain, sehungga berimbas pada perceraian keduanya.

Dari apa yang telah dipaparkan di atas, kebijakan terhadap keharmonisan rumah tangga tahanan telah sesuai dengan ajaran agama Islam dan tujuan untuk menciptakan keharmonisan rumah tangga tahanan juga terpenuhi, hanya saja belum mempunyai payung hukum yang tetap.

\section{Penutup}

Kebijakan Polsek Tandes Surabaya membolehkan tahanan bertemu dengan keluarganya dengan syarat yang telah disepakati oleh tahanan dan petugas Polsek Tandes Surabaya merupakan upaya pengembangan kasus yang sedang dialami tahanan serta menstabilkan emosional tahanan yang sudah berkeluarga. Adapun 
bentuk kebijakan Polsek Tandes Surabaya tersebut telah sejalan dengan maqashidus syari'ah dan konsep maslahah mursalah. Semua itu dapat dilihat dari terpenuhinya lima jaminan dasar kehidupan (keselamatan agama, jiwa, akal, keturunan dan harta) serta terpenuhi syarat-syarat yang ada dalam maslahah mursalah. Hanya saja perhatian pemerintah akan hak dan kewajiban tahanan yang sudah berkeluarga dirasakan masih kurang, sebab di satu sisi tahanan yang berkeluarga mempunyai kewajiban yang tidak bisa dikesampingkan.

Beberapa saran mungkin dapat dijadikan pertimbangan dan masukan bagi pemerintah khususnya serta masyarakat pada umumnya:

1. Bagi pemerintah, dalam membuat sebuah kebijakan yang berhubungan dengan hak dan kewajiban tahanan, hendaknya mempertimbangkan hukum Islam serta lebih memperhatikan sarana dan prasarana tiap tingkatan, termasuk mengatasi kekurangan personil agar penjagaaan tahanan dapat maksimal.

2. Bagi masyarakat, hendaknya memperhatikan nasib keluarganya yang menjadi tahanan, jangan sampai dikucilkan karena bukan tidak mungkin mereka ingin menjadi lebih baik dari sebelumnya.

\section{Daftar Pustaka}

Hakam Abbas. "Pendapat Ulama tentang Kewajiban Suami", dalam http://hakamabbas.blogspot.co.id/2014/02/pendapatulama-tentang-kewajiban-suami.html, diakses pada 10 Nopember 2016.

Amin Abdullah. Marhab Jogja Menggagas Paradigma Ushul Fiqh Kontemporer. Jogjakarta: Ar-Ruzz Press, 2002.

Abdullah, Sulaiman. Sumber Hukum Islam Permasalahannya dan Fleksibelitasnya). Jakarta: Sinar Grafika, 1995.

Noer Iskandar Bansany (al) et. al. Kaidah Kaidah Hukum Islam. Jakarta: Rajawali, 1989.

Abdul Rahman Dahlan. Ushul Fiqh. Jakarta: Amzah, 2010.

M. Dulgani Dahruji (bin). Wawancara. Surabaya, 23 Desember 2016.

Departemen Agama RI. Mushaf Al-Qur'an Terjemah. Jakarta: Departemen Agama RI, 2002.

Departemen Agama. KHI dan UU NO.1 Thn 1974 Tentang Perkawinan. Jakarta: Departeman Agama, 1996. 
Departemen Agama. UU No.1 Thn 1974 dan UU No.7 Thn 1989. Jakarta: Departemen Agama, 1996.

Herman Hosnol Fajar. Wawancara. Polsek Tandes Surabaya, 4 Nopember 2016.

Wahbi Sulaiman Ghawaji. Sosok Wanita Muslimah. Bandung: Trigendi Karya, 1995.

Abd. Rahman Ghazaly. Fiqh Munakahat. Bogor: Kencana, 2003.

Haq, Abdul. Formulasi Nalar Fiqh Telaah Fiqh Konseptual. Surabaya: Khalista, 2009.

Hasanan, Ubaid bin Aziz. "Hukum Berhubang Intim di dalam Penjara", dalam www.fikihkontemporer.com, diakses pada 25 Januari 2017.

Muhammad Ali Al-Hasyimi Hasyimi (al). Sosok Pria Muslim. Jakarta: Trigendi Karya,

Abdul Karim Zaidan. Al-Wajiz, 100 Kaidah Fiqih dalam Kehidupan Sehari-hari, terj. Muhyiddin Masrida. Jakarta: Al-Kautsar, 2008.

Abdul Mannan. Reformasi Hukum Islam di Indonesia. Jakarta: Rajawali Press, 2006.

Jastuti Ningsih. Wawancara. Polsek Tandes Surabaya, 03 Januari 2017.

Hendri Prasetyo. Wawancara. Ruang Penyidik Polsek Tandes Surabaya, 03 Januari 2017.

Muhammad Ridhwi. Perkawinan dan Seks dalam Islam. Jakarta: PT. Lentera Britama, 1996.

Rosullian. Wawancara. Polsek Tandes Surabaya, 12 Nopember 2016. Nasrun Ruali. Konsep Ijtihad As-Syaukhani. Jakarta: Logos, 1999.

Beni Ahmad Saebani. Fiqh Munakahat I. Bandung: Pustaka Setia, 2010.

Rahmat Sudirman. Kontruksi Seksualitas Islam dalam Wacana Islam. Yogyakarta: PT. Media Pressindo, 1999.

Beni Suhartono. Wawancara. Ruang SPK Polsek Tandes Surabaya, 27 Desember 2017.

Amir Syarifuddin. Hukum Perkawinan Islam di Indonesia. Jakarta: Prenada Media, 2007.

-------. Ushul Fiqh, jilid II. Jakarta: PT. Kencana, 2009.

Muhammad Zahrah (abu). UshulFiqh. Jakarta: Putaka Firdaus, 2007. 
Mirza Aziz Didik Putra: Kabijakan Polsek Tandes..

Wahbah Zuhailiy. Usul al-Fiqh al-Islamiy. t.th: t.tp., t.t.. 